Journal of Tourism Management Research

2020 Vol. 7, No. 2, pp. 196-207.

$\operatorname{ISSN}(e): 2313-4178$

$\operatorname{ISSN}(p): 2408-9117$

DOI: $10.18488 /$ journal.31.2020.72.196.207

(C) 2020 Conscientia Beam. All Rights Reserved.

check for
updates

\title{
THE IMPACT OF COVID-19 ON TOURIST CONSUMPTION BEHAVIOUR : A PERSPECTIVE ARTICLE
}

Amina Chebli ${ }^{1+}$ Foued Ben Said ${ }^{2}$

\author{
${ }^{\prime}$ Research Laboratory City Planning and Sustainable Development (VUDD), \\ Polytechnic School of Architecture and Urban Planning (EPAU) El \\ Harrach, Algiers, Algeria. \\ Email:a.chebli@epau-alger.edu.dz \\ ${ }^{2}$ University of Manouba Higher School of Commerce of Tunis (ESCT)- \\ FSEGT - University of Tunis El Manar, Tunisia.
}

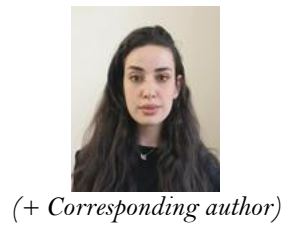

\section{ABSTRACT}

\section{Article History \\ Received: 29 June 2020 Revised: 10 July 2020 Accepted: 15 June 2020 Published: 21 July 2020}

\section{Keywords}

Covid-19

Health crisis

Tourism marketing

Destination management

Tourist behaviour

Resilience.

\begin{abstract}
The study aims to explore the impact of the coronavirus pandemic (Covid-19) on tourist behaviour and identifies intentions to change tourist behaviour that will emerge as a result of this pandemic. In the absence of a similar previous study, this study is designed to be a polite study. 308 travellers, selected on a non-probabilistic basis, participated in this pilot research. The data collected were subjected to Chi-square test of goodness of fit test statistical analysis and content analysis. The results indicate that the current Covid-19 pandemic is expected to have an impact on traveler behavior intentions, in terms of personal safety, economic expenditure, conviction and attitude. Finally, key findings and practical implications of this study are described for the management of this crisis, based on the results and limitations of this research, future research directions are presented. To the best of our knowledge, this paper provides the first exploratory analysis of the consequences that the Covid-19 health crisis is expected to have on travel behaviour.
\end{abstract}

Contribution/Originality: This study contributes to existing literature by exploring the impact of the coronavirus pandemic (Covid-19) on tourist behaviour and identifies intentions to change tourist behaviour that will emerge as a result of this pandemic.

\section{INTRODUCTION}

Tourism is regarded as a substantial industry, accounting for 10 per cent of world GDP, 7 per cent of international trade and 30 per cent of service operations. According to UNWTO, one in 10 jobs is linked to tourism. It is well known that tourism is an activity that contributes to the development of many countries, but despite its economic strength, tourism remains one of the most sensitive and vulnerable sectors to internal and external crises (Sönmez, Apostolopoulos, \& Tarlow, 1999).

Over the last decade, many tourist destinations have experienced crises, ranging from natural to man-made incidents, involving terrorist attacks, health crises (MERS-CoV, SARS...etc.), natural disasters (tsunami, volcanic eruption, hurricane, etc.). Nevertheless, in the aftermath of these crises, the tourism industry has been able to recover. Tourism has an incomparable capacity for resilience (Tejan \& Safaa, 2018) however, unlike previous crises, the world is now facing an unprecedented crisis. The risk is not localized, but it is general and international in scope, with no tourist destination being spared. The UNWTO estimates a 20 to $30 \%$ drop in international arrivals in 2020, which translates into a loss of $\$ 300$ to 450 billion in international tourism revenues Figure 1. Absorbing this shock to establish its resilience is the objective sought by any territory that has built its strategy on tourism. 


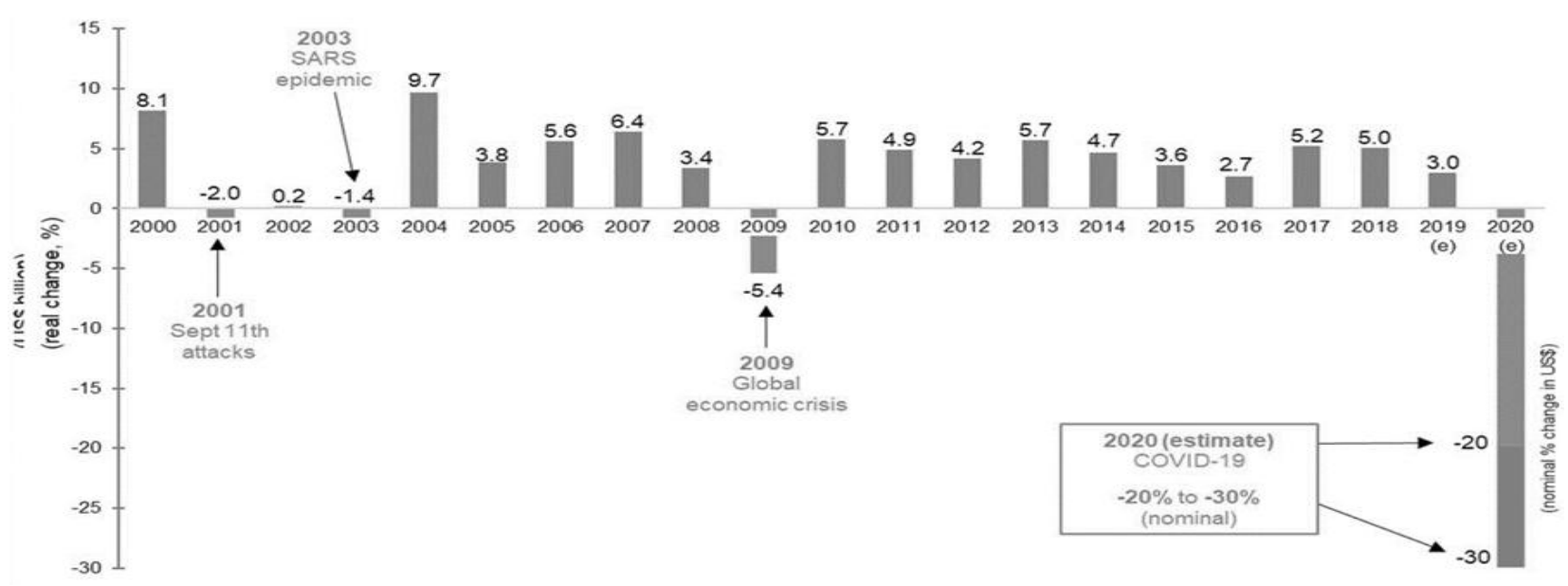

Source: UNWTO

Figure-1. 2020 forecast-international tourism receipts, world (real change, \%).

The resilience of a destination is determined by its ability to react quickly to disturbances and restore stability (Reda, 2018). Thus, to cushion the shock of this crisis, and for an effective response, crisis management is vital. Effective crisis management involves three stages: 1) planning activities, preparation before a crisis occurs, 2) managing the crisis as it occurs, and 3) the final resolution, once the crisis is over (Ritchie, 2009). This study is part of the second stage. By definition, a crisis is "a low-probability, high-frequency event that develops very rapidly and involves ambiguous situations with unknown causes and effects" (Roberts, Madsen, \& Desai, 2007). Faced with the unexpected, such as suddenness of crises, the tourism sector remains vulnerable, subject to severe constraints and in different disaster contexts. In the aftermath of these crises, the tourism industry faces several challenges to recover, including understanding consumer behaviour in response to catastrophic events (Mair, Ritchie, \& Walters, 2016).

Moreover, after each crisis, there is an increase in fear, tension and/or confusion (Bodosca, Gheorghe, \& Nistoreanu, 2014) as tourists are sensitive to crises. Tourist behaviour is the combination of interactions between internal factors (motivation, attitudes, beliefs, etc.) and external factors (economic environment, security, sociocultural environment, etc.) (Andrades, Dimanche, \& Ilkevich, 2015). The authors agree that tourism behaviour results from the processing of stimuli, which are evaluated according to personal preferences and internal characteristics. In addition, external variables modulate perceptions and decisions. In this research, only the external factor, limited to the health risks caused by Covid-19, is taken into account for new tourism behaviour.

For travellers, safety is one of the crucial properties for a consumer (Maslow, 1943). The consumer anticipates a number of disadvantages that arise from the choice of products, so his/her consumption process will consist of developing a strategy to choose a low-risk alternative. Indeed, the perception of risk is of paramount importance in the tourism decision-making process (Sönmez \& Graefe, 1998; Floyd, Gibson, Pennington-Gray, \& Thapa, 2004). Destinations can only attract visitors if they provide a safe and secure environment in which travellers feel protected from threats during their stay (Yousaf, Amin, \& Santos, 2018) when consumers make a decision, they will perceive the risks associated with the purchase of the product. The perception of risk affects consumer behaviour, which in turn influences the choice of purchase. The literature identifies five major risk factors related to tourism, 1) war and political instability, 2) terrorist attacks, 3) crime, 4) natural disasters and5) health concerns.

Faced with the perception of an external danger, the tourist adopts new consumer practices, which has been illustrated in several cases: more trip cancellations (Huang \& Min, 2002) more car trips (Fall \& Massey, 2005) preventing intense contact with people and favouring outdoor activities (Wen, Huimin, \& Kavanaugh, 2005), more last-minute reservations (Hystad \& Keller, 2008) and more concern for hygiene, more attention to ecotourism (Higgins-Desbiolles, 2020). Thus, a question arises: once travel resumes, what will be the new trends in travel? In other words, what are the potential new tourism behaviours that could emerge? As experienced in other cases, after a crisis, new tourist concerns, apprehensions and demands emerge. Therefore, it is considered imperative to predict 
the trajectory of change in tourist behaviour to help tourism managers identify the basis of a resilience strategy to ideally respond to the situation. This pilot research aims to provide a means of reflection by identifying intentions for change in tourist behaviour in the aftermath of Covid-19. It is extremely difficult to predict the behaviour of tourism consumers after a crisis (Vo Thanh, 2006). Therefore, an empirical study was conducted to understand the sensitivity of tourists faced with a health crisis such as that of Covid-19, with the aim of obtaining information from travellers to identify any potential changes in their consumption as a consequence of Covid-19. The evolution of these behaviours was also studied from a temporal perspective. The hypotheses of this research were established on the basis of preconceptions formulated by researchers in their published work (Gössling, Scott, \& Hall, 2020; Higgins-Desbiolles, 2020; Hoque, Shikha, Hasanat, Arif, \& Hamid, 2020) and concerns expressed by tourists on social networks, about the general perception of the impacts of Covid-19 on tourists. Thus, after the Covid-19 crisis, for their next trip:

H.a. Tourists will prefer destinations close to home.

H.b. Tourists will avoid known, expensive destinations.

H.c. Tourists will avoid group trips.

H.e. Tourists will pay more attention to the sanitary (hygienic) standards of the host destination.

H.f. Tourists will be more interested than before in the quality of health care in the host destination.

H.e. Tourists will pay more attention to the choice of travel insurance.

These hypotheses were tested through a survey and statistical analysis of the data.

\section{METHOD}

This research is qualitative research. Two research methods were used to achieve the defined objectives. The first was a questionnaire survey and the second was a content analysis.

\subsection{Survey Instrument}

A self-administered questionnaire was used as the survey tool. This choice made it possible to interview a large number of people while covering a wide geographical area. The method of distribution was via the Internet (social networks). The questionnaire was divided into three sections. In the first section, factual questions were asked, which made it possible to identify the socio-economic dimensions of the population studied. The second section aimed to identify possible changes in tourist behaviour. A 5-point Likert rating scale was used, where $1=$ not at all important, $2=$ not important, $3=$ no opinion, $4=$ important, $5=$ very important. Respondents were asked to rate the level of importance based on their judgment, but in the face of the unknown, it is difficult to predict all the changes that will occur. For this reason, for the third section, respondents were asked to answer an open-ended question on the changes in behaviour that could occur, with the intention of identifying new leads.

\subsection{Selection of Study Variables}

The selection was made in two stages, first a review of the documentation produced on the subject. Second, a content analysis of publications and commentaries, related to general concerns about the effects of Covid-19 on behavioural change, published by travellers in groups on social networks, was conducted. The use of the web as a source of information in the academic discipline of tourism has proven to be a reliable alternative because it is more convenient and less costly than primary field data (Wood, Guerry, Silver, \& Lacayo, 2013). Finally, a total of six study variables were identified, which represent possible changes in tourist behaviour induced by Covid-19.

\subsection{Sampling and Study Population}

A survey of respondents selected using a non-probability method was conducted from 1st to 20th April 2020. A total of 308 travellers took part in the survey; these travellers were invited via social networks. The objective of the 
survey was to trace and contribute to a better understanding of the effects of Covid-19 on tourism. In addition, given the pilot nature of this research, the objective was to collect initial data and to better understand the likely impacts of Covid-19 on tourist behaviour. At this early stage of exploration and prior to conducting further research, non-probability sampling was considered an appropriate sampling technique for this type of study (Nonprobability Sampling, 2008).

\section{RESULTS \& DATA ANALYSIS}

\subsection{Non-Parametric Statistical Test of Chi-Square}

First, the ordinal variable coded according to the Likert scale is translated into a binary variable which takes the value 1 if the consumer attaches importance to the variable studied and zero otherwise. The "no opinion" response is considered as a response that takes the value zero in our Bernoulli variable. The non-parametric Chisquare test of goodness-of-fit was used to analyse changes in tourist behaviour by testing differences in proportions between groups in the dichotomous categorical variable. For each main hypothesis, a hypothesis test was performed.

\section{Hypothesis testing:}

Ho. No importance will be given.

H1. Considerable importance will be attached to $a=1 \%$.

The resulting Chi-square value is compared to a significance level of $1 \%$. If the value obtained is higher, the null hypothesis is rejected. The results of the non-parametric Chi-square test of goodness of fit revealed the variables that tourists value most Table 1 . For the Ha hypothesis, it can be seen in Table 1 that the value of Ho (Chi-square $=82.844, \mathrm{p}=0.000)$ is below the significance level of $1 \%$. Therefore, the null hypothesis $($ Ho) is accepted for the main Ha hypothesis.

Table-1. Behavioural change, percentage and significance.

\begin{tabular}{|c|c|c|c|c|c|c|}
\hline & & $\begin{array}{c}\text { Test } \\
\text { hypotheses }\end{array}$ & Category & Observed Prop. & $\begin{array}{c}\text { Chi- } \\
\text { Square }\end{array}$ & P-value \\
\hline \multirow[t]{2}{*}{$\mathrm{Ha}$} & \multirow{2}{*}{$\begin{array}{l}\text { Choose a destination close to } \\
\text { your region of origin } \\
\text { (proximity) }\end{array}$} & Ho & $\begin{array}{c}\text { Not } \\
\text { important }\end{array}$ & $76.62 \%$ & 82,844 & $0, \mathrm{OOO}^{*}$ \\
\hline & & $\mathrm{H} 1$ & Important & $23.38 \%$ & & \\
\hline \multirow[t]{2}{*}{$\mathrm{Hb}$} & \multirow{2}{*}{$\begin{array}{l}\text { Choose a less well-known } \\
\text { destination, where there will be } \\
\text { fewer tourists }\end{array}$} & Ho & $\begin{array}{c}\text { Not } \\
\text { important }\end{array}$ & $48.37 \%$ & & \\
\hline & & $\mathrm{H} 1$ & Important & $51,62 \%$ & $59,695^{\mathrm{a}}$ & $\mathrm{O}, \mathrm{OOO}^{*}$ \\
\hline \multirow[t]{2}{*}{$\mathrm{Hc}$} & \multirow[t]{2}{*}{$\begin{array}{l}\text { Avoid group travel by bus, } \\
\text { cruise, etc. }\end{array}$} & Ho & $\begin{array}{c}\text { Not } \\
\text { important }\end{array}$ & $38,96 \%$ & & \\
\hline & & $\mathrm{H} 1$ & Important & $61,04 \%$ & 58,299 & $\mathrm{O}, \mathrm{OOO}^{*}$ \\
\hline \multirow[t]{2}{*}{ Hd } & \multirow{2}{*}{$\begin{array}{l}\text { Check on the sanitary } \\
\text { conditions (hygiene, } \\
\text { cleanliness) of the host } \\
\text { destination }\end{array}$} & Ho & $\begin{array}{c}\text { Not } \\
\text { important }\end{array}$ & $26,62 \%$ & & \\
\hline & & $\mathrm{H} 1$ & Important & $73,38 \%$ & 149,240 & $0, \mathrm{OOO}^{*}$ \\
\hline \multirow[t]{2}{*}{$\mathrm{He}$} & \multirow{2}{*}{$\begin{array}{l}\text { Be informed about the quality } \\
\text { of the health care system in the } \\
\text { host destination }\end{array}$} & Ho & $\begin{array}{c}\text { Not } \\
\text { important }\end{array}$ & $33,44 \%$ & & \\
\hline & & $\mathrm{H} 1$ & Important & $66,56 \%$ & 93,688 & O,OOO* \\
\hline \multirow[t]{2}{*}{ Hf } & \multirow[t]{2}{*}{$\begin{array}{l}\text { A carefully considered choice of } \\
\text { your travel insurance }\end{array}$} & Ho & $\begin{array}{c}\text { Not } \\
\text { important }\end{array}$ & $31,82 \%$ & & \\
\hline & & $\mathrm{H} 1$ & Important & $68,18 \%$ & 107,357 & O,OOO* \\
\hline
\end{tabular}

Contrary to the Ha hypothesis, the pandemic has no impact on travellers' preferences when it comes to choosing a destination close to home for their next trip. This is also reflected in the average proportions, with more than $76.62 \%$ stating that for their next vacation, choosing a destination close to home is not an important factor. 
However, the value calculated for the alternative hypothesis $\mathrm{H} 1$ for each of the main hypotheses $\mathrm{Hb}$ (Chi-square $=$ 59.695, $\mathrm{p}=0.000)$, Hc (Chi-square $=58.299, \mathrm{p}=0.000)$, Hd (Chi-square $=149,240, \mathrm{p}=0.000)$, He (Chi-square $=$ 93,688, $\mathrm{p}=0.000), \mathrm{Hf}(\mathrm{Chi}-\mathrm{square}=107,357, \mathrm{p}=0.000)$, is below a significance level of $1 \%$. Therefore, the alternative hypothesis $(\mathrm{H} 1)$ is accepted for these hypotheses.

\subsection{Content Analysis and Open-End Question}

Of the 308 tourists who answered the questionnaire, 116 answered the open-ended question: "In addition to the changes mentioned above, do you think you will change anything else in your tourism behaviour? “. This represents a response rate of $37.6 \%$. A statistical representation of the content was established using the Alyze software, based on the verbatim reports of the respondents. Table 2 is a frequency table of terms, which allowed to identify the most recurrent expressions, indicated by the respondents.

Table-2. Content analysis.

\begin{tabular}{c|l|c|c|c}
\hline N. & Expressions & Weighted (\%) & Gross density (\%) & Occ. \\
\hline 1 & Pay more attention & 0.89 & 1.42 & 8 \\
\hline 2 & Much as possible & 0.89 & 1.42 & 8 \\
\hline 3 & Avoid people as much as possible & 0.84 & 1.89 & 7 \\
\hline 4 & Less money spent & 0.82 & 0.95 & 7 \\
\hline 5 & Limit air travel & 0.82 & 0.95 & 7 \\
\hline 6 & Avoid food outdoors & 0.82 & 0.95 & 7 \\
\hline 7 & Reduce my travel budget & 0.74 & 1.26 & 7 \\
\hline 8 & Wear a mask & 0.6 & 0.95 & 7 \\
\hline 9 & Travel more ecologically & 0.6 & 0.95 & 7 \\
\hline 10 & Do not eat out & 0.57 & 1.26 & 7 \\
\hline 11 & Reduce impact on the environment & 0.55 & 1.26 & 7 \\
\hline 12 & Look for more information & 0.55 & 1.26 & 7 \\
\hline 13 & Avoid high season & 0.47 & 0.95 & 3 \\
\hline 16 & Crowded places & 0.47 & 0.95 & 3 \\
\hline 17 & Social distancing & 0.47 & 0.95 & 3 \\
\hline 18 & Checking the news & 0.47 & 0.95 & 3 \\
\hline 19 & Safety measures & 0.3 & 0.63 & 2 \\
\hline 20 & Air travel low-cost & 0.3 & 0.63 & 2 \\
\hline 21 & Gel & 0.3 & 0.47 & 3 \\
\hline
\end{tabular}

This content analysis allowed to analyse the content of the answers and to identify the key words. The frequent use of these terms may also represent the possible tourist behaviours that could arise as a result of this health crisis. The gross density and weighted indices in Table 1 indicate that, expressions such as "less money spent" (0.82) or "reduce my travel budget" (0.74) refer to the financial aspect; where, "travel more ecologically" (0.6) and "reduce the impact on the environment" (0.55) refer to travel practices. In addition, expressions such as "avoid eating out" (0.82) or "do not eat out" (0.57) refer to eating habits, while "avoid the high season" (0.47) refer to the high tourist season. The expressions "seek more information" (0.55) and "checking the news" (0.47) are also the most recurrent ones, i.e. they appear most often in tourist responses.

\section{DISCUSSION}

\subsection{Intentions Regarding Changes in Tourism Behaviour}

\section{a. Choosing a Close Destination}

The answer to the first question, whether in the future tourists will choose a destination closer to their region of residence, seems to be negative, with a percentage of $76.62 \%$. This result suggests that the Covid-19 pandemic has not had an impact on people's desire to travel away from home and continue exploring across borders. The pandemic does not appear to be creating a desire to discover. This result also suggests that once travel restrictions 
are lifted, long-distance travel would resume, as before, which is quite positive for the tourism industry. The willingness of tourists to continue to travel is reassuring, although people may be "a little more cautious and attentive" to the recovery. Table 1 shows that some prevention mechanisms, such as wearing a mask or disinfectant gel, avoiding gatherings, seem to be reflected in people's behaviour.

Faced with this willingness to continue travelling, despite the concern, industry officials should consolidate the confidence of tourists, by increasing the level of sanitation and strengthening disinfection procedures (means of transport, tourist attractions). They should also encourage them to travel more, such as by making it more convenient to access visas for temporary tourism, taking advantage of more digital processing, electronic visas, to avoid delays and interaction with groups of people. Another suggestion is to offer several credit formulas at preferential rates to tour operators, etc.

\section{b. Choosing a Less Known Destination}

Many tourists agree that for their next trip, they wish to choose a less popular destination Table 1; 51.62\% of the population surveyed proclaim this important choice. It can be deduced that this choice is a combination of internal motivations, such as anxiety and fear, fear of being contaminated, or of catching a disease by finding oneself in a crowd, surrounded by many strangers, whose state of health is unknown. As the results show, travelling to less crowded places may be the new trend. This desire to be away from the crowds in an atypical destination could be an opportunity for the emergence of new destinations, whose managers could use this condition to promote themselves and create an original and atypical destination image. Rural tourism could also be a solution for the future.

This condition can also be interpreted as a desire on the part of tourists to break with the practices of mass tourism, and thus as a precursor to the beginning of the end of mass tourism. Cities affected by over-tourism should therefore adapt to the new requirements by rethinking their economic model, moving towards a softer economy and putting an end to mass tourism, considering measures such as a maximum quota of daily visitors. Managers could thus seize this opportunity to give themselves a new vocation and move towards more responsible tourism.

\section{c. Group Travel}

According to the survey results, the Covid-19 crisis will have an impact on the propensity of tourists to travel in groups and on the purchase of tour packages. The strong consensus of respondents to temporarily suspend group travel, with one percent (61.04\%), can be explained as follows: the fear of being in a closed space (bus, boat, etc.), where one cannot take distance, and also, the anxiety of being stuck in the middle of the ocean, far from the surface, in the case of a cruise. The images and testimonies about the journey experienced by the travellers, quarantined during their cruise on the Costa Favolosa at the beginning of the crisis, will continue to feed the imagination of tourists. This position is also a state of mind; after being confined to their homes for months during the Covid-19 period, people would have a strong desire for independence, a desire for free will and control. For example, group trips may be suspended because individual freedom is reduced and subject to the constraints of an organised programme.

\section{d. Sanitary Condition and Quality of Care at the Destination}

The Covid-19 pandemic has placed hygiene and quality of public care in a very important position Table 1. According to the results of this survey, it can be said that one of the major impacts of this health crisis is hygiene and health awareness. This indicates that for their next trip, travellers would be more concerned about the cleanliness of airports, public spaces, hotels, restaurants, tourist attractions and daily necessities, etc., but also about the conditions of access and the quality of the care offered, by the destination. Thus, health standards, and the performance of the host destination's health system, become factors that influence the travel decision. Faced with more cautious tourists, popular tourist destinations for safaris, trekking, etc., such as certain regions of Asia or 
Africa, risk being abandoned by fearful tourists because of their health system which, according to the World Health Organization report, remains weak with inadequate hygiene conditions (water, sanitation).

\section{e. Travel Insurance}

According to Hajibaba, Gretzel, Leisch, and Dolnicar (2015) purchasing travel insurance is not always a priority. Tourists tend to be reluctant to buy travel insurance, either out of ignorance or simply out of a desire to save money. The results of the survey Table 1 show that after the crisis, this indifference will change, as tourists will no longer be willing to take risks. The strong interest $(68.18 \%)$ of respondents in making informed choices about appropriate travel insurance for their next trip may be due to a number of factors (external and internal).

What is happening today has the potential to happen again, on a temporary basis, as the number of epidemics due to infectious diseases has increased fivefold in a few decades (Bedford et al., 2019). In a connected world, epidemics do not remain locally confined, but spread to neighbouring countries. No individual is immune. There is concern about finding oneself in a critical situation due to an unexpected health problem or infection on one's next trip and having to pay excessively high prices for treatment in a foreign country.

In addition, the feedback from people who bought travel before the crisis hit (hotel reservations, ticket purchases) and who, without trip cancellation and interruption insurance, find themselves losing a considerable amount of money, is also a factor in raising awareness. On the other hand, the disappointment of travellers who have taken tickets from low-cost companies that are non-refundable or whose dates cannot be changed Table 2 . Without insurance covering flight cancellation costs, these tourists are at a disadvantage. Faced with frustrated tourists, these companies should probably consider their refund policy, or at least the possibility of changing ticket dates, to regain the confidence of travellers.

\subsection{Other Predictable Behaviour}

a. Purchasing Power

Another likely behaviour is a decrease in the amount of income allocated to vacations. The economic crisis linked to Covid-19 will have repercussions on purchasing power. With the economic crisis, according to the results of the open-ended question, tourists will try to reduce their travel expenses Table 2 either by targeting more affordable destinations, seeking special offers or shortening the length of their stay. This behaviour after a financial crisis is common and has already been observed. According to Bronner and De Hoog (2012); Bronner and De Hoog (2016) after an economic crisis, consumers adopt several attitudes: saving, new ways of spending money, changing travel planning strategies, and changing consumer practices. Such a change could be an opportunity to revitalize domestic tourism and build customer loyalty. Travellers will have lower transportation costs, especially since air fares may increase as flights resume. According to forecasts by the International Air Transport Association (IATA), ticket prices could increase by $50 \%$.

\section{b. Restoration Practices}

At the beginning of the crisis, it was reiterated that the origin of the pandemic is the consumption of wild animals. This could explain the answer obtained to the open-ended question, in which tourists said they wanted to avoid eating exotic meals, which are unusual for them. Some respondents said they prefer to prepare their own food for their next trip and avoid eating in restaurants Table 2.

\section{c. Environmental Awareness}

The regained transparency of the canals in Venice, Italy, following the suspension of tourist boat traffic, is an emblematic image widely disseminated by the media, and will long mark the minds of tourists. This image clearly shows the impact of the tourism industry on the environment. The pandemic is making tourists more 
environmentally conscious Table 2. According to the responses to the open-ended question, travellers declare that they want to travel in the future in a more "ecological", "responsible", "minimalist" and "nomadic" way. These words are the main adjectives used to describe their futuristic aspirations for greener tourism. After a health crisis, people's sensitivity to ecotourism, and support for outdoor activities, is growing.

The emergence of such behaviours was also highlighted by Wen et al. (2005) in the aftermath of the SARS (Severe Acute Respiratory Syndrome) pandemic. The increase in environmental awareness could be accompanied by an increase in demand for ecotourism. It is likely that ecotourism will become more popular in the future. Therefore, it is important for destinations operating in this growing market segment to anticipate the strong pressure that these environments may come under and to ensure that development is rational, while at the same time raising awareness of the natural environment.

\section{d. The Search for Information}

Tourists also expressed their willingness to learn more and to follow current information about the travel destination before making a final decision about their next trip Table 2. The provision of clear, accessible and up-todate information is essential for attracting tourists and influencing their decisions (Lehto, Douglas, \& Park, 2008). After such a global panic, to attract tourists and restore their confidence, it is possible for a destination to act and influence the mental representations associated with its territory through a large measure of advertising and promotion. Indeed, massive communication measures are recommended to stem the many misperceptions that can follow disasters (Carlsen \& Hughes, 2008).

Focusing on, promoting and disseminating a safe and responsible country is a strategy that several Asian destinations (Singapore, Thailand, Vietnam and Hong Kong) adopted after the SARS epidemic. This strategy has allowed them to repair an image disturbed by stereotypes and bring back visitors (Avraham \& Ketter, 2017). The image projected by a destination is a very influential factor (Chon, 1990). For tourism managers, increasing communication efforts through different channels should be an important part of the resilience process.

\section{e. Travelling during Low Season}

The last likely behaviour of tourists revealed by this study is the desire of travellers to avoid travelling during the high season Table 2 which could be the result of several factors identified in the study, namely: the resolution to avoid crowds of people and, perhaps, the high cost of travel at this time of year Table 1. This travel period orientation, which could eventually take place, should be exploited by tourism managers as a windfall to reduce the negative effects of tourism seasonality. These are particularly economic in nature and affect the profitability of businesses (Pegg, Patterson, \& Gariddo, 2012). The motivation to travel in low season (push factor) is present, and faced with this, tourism managers should think about strategies to attract more tourists (pull factors): make marketing efforts, and better structuring of the offer: create season-specific packages of unique experiences, exclusive offers at reduced rates in off-peak periods, etc.

\section{CONCLUSION}

Due to the global panic caused by Covid-19, the pandemic is having an effect on travel intentions. Therefore, stakeholders in the tourism industry need to be resilient and consider how to overcome all the apocalyptic predictions. This study aimed to provide an exploratory overview of the changing behaviour of tourists in a society at risk.

\subsection{Implications}

One of the objectives of this work was to predict intentions regarding changes in tourism behaviour that might occur after the Covid-19 health crisis. Understanding fluctuating tourist behaviour is a context that guides 
strategies and actions to provide adequate response measures for the recovery of the tourism industry. The results of this research could thus serve as a basis for reflection for destination marketers and crisis managers seeking to bounce back from this crisis. The study identified a total of ten likely changes in behaviour. These results are in line with previous studies, which reveal the sensitivity of tourists to crises. Statistical analysis showed that of the total of six variables in the study, five were significant predictors of intention to change in the future. In addition, the semantic analysis allowed identifying another five variables.

Thus, it can be concluded that Covid-19 will influence travel habits, and people will avoid travelling in groups, and being surrounded by a group of people. They will also avoid the risk of travelling without travel insurance. This pandemic has drawn the attention of the general public to the issue of hygiene and health. Hygiene and health conditions in the host destination will become important factors in travel decisions. Faced with a worried clientele, tourism businesses (transport, accommodation, catering, tourist attraction facilities) should further improve their hygiene conditions, to regain confidence.

Due to the economic crisis, tourists would be more cautious about travel spending. Thus, to avoid abandoned destinations, even after the crisis, it is important to consider attractively priced offers that could possibly seduce and attract tourists as soon as the offer is adapted to their financial situation. Tourists say that they will refrain from eating outdoors, and that they will be more involved in respecting nature and practising more responsible tourism. This crisis is seen as an opportunity to transform their consumption practices. For their next trip, tourists would also be more information-seeking. It is therefore recommended that tourism managers focus on a media strategy, cultivate positive images and stimulate tourism during and after the crisis. Furthermore, motivating tourists to travel during low season is an opportunity for managers to raise awareness of the low season by presenting the advantages of such travel and the opportunities it offers (attractions, activities, services, etc.). It is also an opportunity for managers to build customer loyalty by changing their perception of travel in the low season.

\subsection{Limitations and Recommendation for Future Research}

This study has several limitations; there is always a gap between intentions and actual behaviour (McKercher \& Hui, 2004). Thus, it is essential to conduct future research on consumer psychology to understand, and more specifically predict, the direction in which behaviour change will take place. It addition, future research will allow to better understand the influence of the crisis (Covid-19) on travel intentions (identified) and actual behaviour (that will occur). Second, the purpose of this research is exploration, to approximately identify the impact of Covid-19 on tourism behaviour, generalisation to a wider population is not the aim of this paper. Thus, the sampling technique approved for this research is non-probability sampling, which infers a lack of representativeness and limits the possibility of generalisation of the results obtained. For a more reliable and broad interpretation, it is therefore recommended to proceed to a survey of selected respondents using a probability method.

The third point, is that the behaviour change identified in this study is not specific to a particular region. No specific geographic context, defined as a container, was used to study behaviour change, therefore responses could have varied. Future research should study the behavioural change intentions of tourists in relation to a specific context (at the level of regions, as defined above). The context of future studies may reveal other behaviours, which did not emerge during the course of this study. Finally, tourism behaviour is also defined by internal factors (Beerli \& Martín, 2004; Chebli, Chabou, \& Ben, 2020) such as socio-demographic factors (age, gender, origin). In this study, the tourism market was not segmented. Thus, for future research, studying the behaviour of each segment independently will allow managers to act more specifically according to expectations based on: age, gender, and origin. As forecasts become more accurate, better defined and understood, recovery strategies could be better controlled and targeted to ensure maximum effectiveness. 
Funding: This study received no specific financial support.

Competing Interests: The authors declare that they have no competing interests.

Acknowledgement: Both authors contributed equally to the conception and design of the study.

\section{REFERENCES}

Andrades, L., Dimanche, F., \& Ilkevich, S. (2015). Chapter 4: Tourist behaviour and trends In book: Tourism in Russia: A management handbook: Emerald Editors.

Avraham, E., \& Ketter, E. (2017). Destination marketing during and following crises: Combating negative images in Asia. Journal of Travel \& Tourism Marketing, 34(6), 709-718.Available at: https://doi.org/10.1080/10548408.2016.1237926.

Bedford, J., Farrar, J., Ihekweazu, C., Kang, G., Koopmans, M., \& Nkengasong, J. (2019). A new twenty-first century science for effective epidemic response. Nature, 575(7781), 130-136.Available at: https://doi.org/10.1038/s41586-019-1717-y.

Beerli, A., \& Martín, J. D. (2004). Factors influencing destination image. Annals of Tourism Research 31(3), 657-681.Available at: https://doi.org/10.1016/j.annals.2004.01.010.

Bodosca, S., Gheorghe, S., \& Nistoreanu, P. (2014). Tourist consumption behaviour before and after the crisis from 2008. Paper presented at the 21 st International Economic Conference 2014, IECS 2014, 16-17 May 2014, Sibiu, Romania. Procedia Economics and Finance.

Bronner, F., \& De Hoog, R. (2016). Crisis resistance of tourist demand: The importance of quality of life. Journal of Travel Research, 55(2), 190-204.Available at: https://doi.org/10.1177/0047287514541006.

Bronner, F., \& De Hoog, R. (2012). Economizing strategies during an economic crisis. Annals of Tourism Research, 39(2), 10481069.Available at: https://doi.org/10.1016/j.annals.2011.11.019.

Carlsen, J. C., \& Hughes, M. (2008). Tourism market Rrecovery in the Maldives after the 2004 Indian Ocean Tsunami. Journal of Travel \& Tourism Marketing, 23(2-4), 139-149.Available at: https://doi.org/10.1300/Jo73v23no2_11.

Chebli, A., Chabou, O. M., \& Ben, S. F. (2020). Market segmentation in urban tourism: Exploring the influence of personal factors on tourists' perception. Journal of Tourism and Services, 20(1), 74-108.Available at: 10.29036/jots.v 1 1i20.144.

Chon, K. (1990). The role of destination image in tourism: A review and discussion. The Tourist Review 45(2), -9.Available at: https://doi.org/10.1108/eb058040.

Fall, L. T., \& Massey, J. E. (2005). The significance of crisis communication in the aftermath of 9/11: A national investigation of how tourism managers have Re-Tooled their promotional campaigns. Journal of Travel \& Tourism Marketing, 19(2-3), 77-90.Available at: https://doi.org/10.1300/J073v19no2_07.

Floyd, M. F., Gibson, H., Pennington-Gray, L., \& Thapa, B. (2004). The effect of risk perceptions on intentions to travel in the aftermath of September 11, 2001. Journal of Travel \& Tourism Marketing, 15(2-3), 19-38.Available at: https://doi.org/10.1300/J073v15n02_02.

Gössling, S., Scott, D., \& Hall, C. M. (2020). Pandemics, tourism and global change: A rapid assessment of COVID-19. Journal of Sustainable Tourism, 1-20.Available at: https://doi.org/10.1080/09669582.2020.1758708.

Hajibaba, H., Gretzel, U., Leisch, F., \& Dolnicar, S. (2015). Crisis-resistant tourists. Annals of Tourism Research, 53, 4660.Available at: https://doi.org/10.1016/j.annals.2015.04.001.

Higgins-Desbiolles, F. (2020). Socialising tourism for social and ecological justice after COVID-19. Tourism Geographies, 114.Available at: https://doi.org/10.1080/14616688.2020.1757748.

Hoque, A., Shikha, F. A., Hasanat, M. W., Arif, I., \& Hamid, A. B. A. (2020). The effect of coronavirus (COVID-19) in the tourism industry in China. Asian Journal of Multidisciplinary Studies, 3(1), 52-58.

Huang, J.-H., \& Min, J. C. H. (2002). Earthquake devastation and recovery in tourism: The Taiwan case. Tourism Management, 23(2), 145-154.Available at: https://doi.org/10.1016/So261-5177(01)00051-6.

Hystad, P. W., \& Keller, P. C. (2008). Towards a destination tourism disaster management framework: Long-term lessons from a forest fire disaster. Tourism Management, 29(1), 151-162.Available at: https://doi.org/10.1016/j.tourman.2007.02.017. 
Lehto, X., Douglas, A. C., \& Park, J. (2008). Mediating the effects of natural disasters on travel intention. Journal of Travel \& Tourism Marketing, 23(2-4), 29-43.Available at: https://doi.org/10.1300/J073v23n02_03.

Mair, J., Ritchie, B. W., \& Walters, G. (2016). Towards a research agenda for post-disaster and post-crisis recovery strategies for tourist destinations: A narrative review. Current Issues in Tourism, 19(1), 1-26.Available at: https://doi.org/10.1080/13683500.2014.932758.

Maslow, A. H. (1943). A theory of human motivation. Psychological Review, 50(4), 370-396.Available at: https://doi.org/10.1037/ho054346.

McKercher, B., \& Hui, E. L. L. (2004). Terrorism, economic uncertainty and outbound travel from Hong Kong. Journal of Travel \& Tourism Marketing 15(2-3), 99-115.Available at: https://doi.org/10.1300/J073v15no2_06.

Nonprobability Sampling. (2008). In L. Given, The SAGE encyclopedia of qualitative research methods: SAGE Publications, Inc.

Pegg, S., Patterson, I., \& Gariddo, P. V. (2012). The impact of seasonality on tourism and hospitality operations in the alpine region of New South Wales, Australia. International Journal of Hospitality Management, 31(3), 659-666.Available at: https://doi.org/10.1016/j.ijhm.2011.09.001.

Reda, K. M. (2018). Organizational resilience as a tool for reviving a destination. The case of Quebec. Caribbean Studies, 2.Available at: https://doi.org/10.4000/etudescaribeennes. 14021.

Ritchie, B. W. (2009). Crisis and disaster management for tourism: Channel View Publications.

Roberts, K. H., Madsen, P., \& Desai, V. (2007). Organizational Sensemaking during Crisis. In: Pearson, C.M., Roux-Dufort, C. and Clair, J.A., Eds., International Handbook of Organizational Crisis Management (pp. 109-122). Los Angeles: Sage Publications.

Sönmez, S. F., \& Graefe, A. R. (1998). Determining future travel behavior from past travel experience and perceptions of risk and safety. . Journal of Travel Research, 37(2), 171-177.Available at: https://doi.org/10.1177/004728759803700209.

Sönmez, S. F., Apostolopoulos, Y., \& Tarlow, P. (1999). Tourism in crisis: Managing the effects of terrorism. Journal of Travel Research(138), 13-18.Available at: https://doi.org/10.1177/004728759903800104.

Tejan, M. A., \& Safaa, L. (2018). Crises, learning and resilience: Retrospective analysis of tourist activity in Morocco from 1991 to 2016. Focus on the destination Marrakech. Caribbean Studies, 2.Available at: https://doi.org/10.4000/etudescaribeennes.13975.

Vo Thanh, T. (2006). Time for risks: A marketing approach for a tourist destination in the face of the new global tourism context. The Journal of Management Sciences, 222(6), 35-45.Available at: https://doi.org/10.3917/rsg.222.0035.

Wen, Z., Huimin, G., \& Kavanaugh, R. R. (2005). The impacts of SARS on the consumer behaviour of Chinese domestic tourists. Current Issues in Tourism, 8(1), 22-38.Available at: https://doi.org/10.1080/13683500508668203.

Wood, S., Guerry, A., Silver, J., \& Lacayo, M. (2013). Using social media to quantify nature-based tourism and recreation. Scientific Reports, 3, 2976.Available at: 10.1038/srep02976.

Yousaf, A., Amin, I., \& Santos, J. A. (2018). Tourist's motivations to travel: A theoretical perspective on the existing literture. Tourism and Hospitality Management, 24(1), 1-15.Available at: https://doi.org/10.20867/thm.24.1.8. 


\section{APPENDIX}

Research Questionnaire

Preparing for the aftermath of the pandemic (Covid-19), changes in tourist behaviours

\section{Section I. Factual questions}

Q1. What age group do you belong to? *

Under 18

18 years 34 years

35 years 49 years

50 years 65 years

Over 65

Q2. What is your gender? *

Male

Female

Q3. What is your region of residence? *

Africa

Asia Pacific

America

Europe

Section II. Intentions for change in tourism behaviour

Change in tourist behaviour: it is said, that there will be a before and after Covid-19, to what extent this health crisis will change our perception of travel.

Q4. In the aftermath of the pandemic, as you prepare for your next trip, you will be attentive to the fact that *

\begin{tabular}{|c|c|c|c|c|c|}
\hline & $\begin{array}{l}\text { Not at all } \\
\text { important }\end{array}$ & $\begin{array}{l}\text { Not } \\
\text { important }\end{array}$ & $\begin{array}{l}\text { Without } \\
\text { opinion }\end{array}$ & Important & $\begin{array}{l}\text { Very } \\
\text { important }\end{array}$ \\
\hline \multicolumn{6}{|l|}{$\begin{array}{l}\text { Choose a destination close to your } \\
\text { region of origin (proximity) }\end{array}$} \\
\hline \multicolumn{6}{|l|}{$\begin{array}{l}\text { Choose a less well-known destination, } \\
\text { where there will be less tourist crowds. }\end{array}$} \\
\hline \multicolumn{6}{|l|}{ Avoid group travel by bus , cruise...etc. } \\
\hline \multicolumn{6}{|l|}{$\begin{array}{l}\text { Be informed about the quality of the } \\
\text { health care system in the host } \\
\text { destination }\end{array}$} \\
\hline \multicolumn{6}{|l|}{$\begin{array}{l}\text { A carefully considered choice of your } \\
\text { travel insurance (health coverage, } \\
\text { baggage insurance, trip cancellation and } \\
\text { interruption insurance, etc.). }\end{array}$} \\
\hline $\begin{array}{l}\text { Check on the sanitary conditions } \\
\text { (hygiene, cleanliness) of the host } \\
\text { destination }\end{array}$ & & & & & \\
\hline
\end{tabular}

Section III. Open Question

Q6. In addition to the changes mentioned above, do you plan to change anything else in your tourism behaviour? 